\title{
A Statistical Approach to the Synoptic Climatology of Vertical Ozone Distributions
}

\author{
A. B. Pittock \\ Division of Meteorological Physics, CSIRO, Aspendale, Australia \\ 2 October 1968 and 6 November 1968
}

The data from 208 ozone soundings over Aspendale, Australia (385, 145E), during 1965-68 and 336 ozone soundings over Boulder, Colo. ( $40 \mathrm{~N}, 105 \mathrm{~W}$ ), during 1963-65, obtained with Mast-Brewer ozonesondes, have been classified according to the synoptic weather pattern to give a picture of the synoptic climatology of ozone in middle latitudes. Preliminary results are given below. A more detailed study will be presented elsewhere.

A description of the methods of obtaining and processing the data will be found in Pittock (1968). The Aspendale data are being published in "Ozone Data for the World" (Meteorology Branch, Department of Transport, Toronto) and the Boulder data will be found in Duitsch (1966).

Synoptic charts used were those drawn on an operational basis by the Commonwealth Bureau of Meteorology in Melbourne, which, however, are not published. For Boulder the Northern Hemisphere charts drawn at the Free University, Berlin, were used (Freien Universität, 1963-65).

The ozone soundings were classified, separately for Aspendale and Boulder, according to the position of the station in relation to the 300 -mb synoptic pattern. The classification scheme consists of a two-way classification into six columns and three rows.

Columns numbered $j=1-6$ represent synoptic situations in which the station is in or near a ridge, east of a ridge, west of a trough, in or near a trough or cut-off low, east of a trough, and west of a ridge, respectively.

Row classification $i=1-3$ is relative to the middle latitude jet stream. Thus, for column 1 : in row 1 the station is more than $15^{\circ}$ of latitude equatorward of the jet, in row 2 between $5^{\circ}$ and $15^{\circ}$ of latitude equatorward of the jet, and in row 3 less than $5^{\circ}$ equatorward of the jet. In columns $2,3,5$ and 6 row 1 is more than $5^{\circ}$ of latitude equatorward of the jet, row 2 less than $5^{\circ}$ equatorward of the jet, and row 3 is in or poleward of the jet. In column 4 , row 1 is more than $5^{\circ}$ equatorward of the jet, row 2 is in or less than $5^{\circ}$ equatorward of the jet, and row 3 is poleward of the jet or within a cut-off low.

The classes so defined are thus identified by their row and column numbers $(i, j)$. They form a very approximate rectangular grid on a typical synoptic map, and, for the stations concerned, practically every sonde flight can be assigned a place in one of the classes. The classification would have to be extended or modified for stations at other latitudes.

Mean vertical distributions of ozone, with standard errors of the means, were then computed for each synoptic classification. As it became clear that significant seasonal differences occurred within the same classes, the classification was further subdivided into two "seasons" each of six months. These are summerautumn, extending from December through May at Aspendale, and from June through November at Boulder, and denoted "S-A" in Table 1, and conversely for winter-spring which is denoted "W-S." What might be termed "pseudo-space cross sections" of ozone number mixing ratio (the ratio of the number of ozone molecules to the number of air molecules) were then constructed for typical east-west and northsouth cross sections through ridges, troughs and jetstreams.

Such a procedure and classification scheme is obviously crude, making no satisfactory allowance for multiple jet streams (doubtful cases were decided subjectively), nor for the varying intensity and depth of the systems. The division into only two "seasons" is obviously not ideal, but the limited number of soundings makes it impracticable at present to subdivide the data further. Even the present crude subdivision reduces the number of cases in some classes to too few for statistically satisfactory conclusions. ${ }^{1}$

The results of the analysis, in terms of mean ozone partial pressures $\bar{p}_{8}(\mu \mathrm{mb})$ and the standard errors of the means (SE), at various standard pressure levels, are given in Table 1 for classes $(1,2)$ and $(3,4)$. Class $(1,1)$ was not well represented in the populations at either Aspendale or Boulder, so classes $(1,2)$ and $(3,4)$ are the most extreme classes containing a satisfactory number of cases. The data for all years were combined, except in the last two columns of the table where, for Boulder, there were sufficient cases to warrant a further subdivision into different years. The number $N$, of

\footnotetext{
${ }^{1}$ In regard to the possibility that seasonal variations in the position of the jet stream may cause aliasing into meridional changes, there are several reasons for thinking such an effect is not serious in the present analysis. Thus,

1) the dates of individual soundings included in the various classes do not show serious bunching toward atypical months within the "seasons," e.g., Aspendale class $(2,4) \mathrm{W}-\mathrm{S}$ dates are 8 October 1965, 13 July 1966, 30 September 1966, and 27 September 1967;

2) individual soundings in different meridional classifications, but in the same months, are consistent with the mean picture derived from the meridional classification;

3) the subdivision into two six-month "seasons" increased the differences between meridional classes in the W-S season as compared with all seasons combined; and

4) the results agree well with known features of the circulation in the vicinity of the middle-latitude jet stream.
} 
TABLE 1. Mean ozone partial pressure $\bar{p}_{3}$ and their standard errors SE (both $\mu \mathrm{mb}$ ), at standard pressure levels, for classes $(1,2)$ and $(3,4)$ in the summer-autumn (S-A) and winter-spring (W-S) seasons over Aspendale (38S) and Boulder $(40 N)$. The number $N$ of soundings and mean total ozone amount $\bar{D}(\mathrm{~m}$ atm-cm) are given for each subdivision.

\begin{tabular}{|c|c|c|c|c|c|c|c|c|c|c|c|}
\hline \multirow{3}{*}{$\begin{array}{l}\text { Level } \\
\text { (mb) }\end{array}$} & & \multicolumn{4}{|c|}{ Aspendale } & \multicolumn{6}{|c|}{ Boulder } \\
\hline & & & \multicolumn{2}{|c|}{$\begin{array}{l}\text { Class } \\
(3,4)\end{array}$} & \multicolumn{2}{|c|}{$\begin{array}{l}\text { Class } \\
(1,2)\end{array}$} & \multicolumn{3}{|c|}{ Class $(3,4)$} & \multirow{2}{*}{$\begin{array}{c}\text { W-S } \\
1964-65\end{array}$} \\
\hline & & S-A & W-S & S-A & W-S & S-A & W-S & S-A & W-S & $\begin{array}{c}\text { W-S } \\
1963-64\end{array}$ & \\
\hline 1000 & $\begin{array}{l}p_{3} \\
\mathrm{SE}\end{array}$ & $\begin{array}{r}16.4 \\
2.6\end{array}$ & $\begin{array}{r}21.2 \\
2.5\end{array}$ & $\begin{array}{r}16.6 \\
2.3\end{array}$ & $\begin{array}{r}20.3 \\
1.0\end{array}$ & - & - & - & - & E & - \\
\hline 700 & $\begin{array}{l}p_{3} \\
\mathrm{SE}\end{array}$ & $\begin{array}{r}20.8 \\
1.0\end{array}$ & $\begin{array}{r}23.5 \\
1.3\end{array}$ & $\begin{array}{r}19.0 \\
3.8\end{array}$ & $\begin{array}{r}20.6 \\
0.5\end{array}$ & $\begin{array}{r}29.7 \\
1.5\end{array}$ & $\begin{array}{r}28.1 \\
1.7\end{array}$ & $\begin{array}{r}29.7 \\
3.1\end{array}$ & $\begin{array}{r}26.8 \\
1.2\end{array}$ & $\begin{array}{r}24.5 \\
2.0\end{array}$ & $\begin{array}{r}28.4 \\
1.4\end{array}$ \\
\hline 400 & $\begin{array}{l}\bar{p}_{3} \\
\mathrm{SE}\end{array}$ & $\begin{array}{r}15.4 \\
1.5\end{array}$ & $\begin{array}{r}18.5 \\
1.8\end{array}$ & $\begin{array}{r}18.7 \\
3.2\end{array}$ & $\begin{array}{r}14.1 \\
0.7\end{array}$ & $\begin{array}{r}19.9 \\
1.7\end{array}$ & $\begin{array}{r}17.4 \\
1.4\end{array}$ & $\begin{array}{r}22.8 \\
3.5\end{array}$ & $\begin{array}{r}21.7 \\
0.9\end{array}$ & $\begin{array}{r}20.8 \\
1.6\end{array}$ & $\begin{array}{r}22.4 \\
1.1\end{array}$ \\
\hline 300 & $\begin{array}{l}\bar{p}_{3} \\
\mathrm{SE}\end{array}$ & $\begin{array}{r}14.4 \\
1.4\end{array}$ & $\begin{array}{r}18.2 \\
2.1\end{array}$ & $\begin{array}{r}25.4 \\
8.5\end{array}$ & $\begin{array}{r}38.6 \\
7.9\end{array}$ & $\begin{array}{r}16.1 \\
1.5\end{array}$ & $\begin{array}{r}14.6 \\
1.6\end{array}$ & $\begin{array}{r}25.2 \\
5.5\end{array}$ & $\begin{array}{r}39.6 \\
3.5\end{array}$ & $\begin{array}{r}35.9 \\
5.1\end{array}$ & $\begin{array}{r}42.2 \\
4.7\end{array}$ \\
\hline 200 & $\stackrel{p_{3}}{\mathrm{SE}}$ & $\begin{array}{r}21.5 \\
4.9\end{array}$ & $\begin{array}{r}39.2 \\
8.1\end{array}$ & $\begin{array}{r}46.0 \\
3.9\end{array}$ & $\begin{array}{r}71.6 \\
6.4\end{array}$ & $\begin{array}{r}15.1 \\
2.5\end{array}$ & $\begin{array}{r}20.4 \\
2.8\end{array}$ & $\begin{array}{l}44.8 \\
12\end{array}$ & $\begin{array}{r}83.2 \\
4.3\end{array}$ & $\begin{array}{r}86.8 \\
8.5\end{array}$ & $\begin{array}{r}80.6 \\
4.2\end{array}$ \\
\hline 140 & $\stackrel{p_{3}}{\mathrm{SE}}$ & $\begin{array}{r}26.8 \\
7.8\end{array}$ & $\begin{array}{r}41.7 \\
5.8\end{array}$ & $\begin{array}{l}39.7 \\
13\end{array}$ & $\begin{array}{r}58.6 \\
4.9\end{array}$ & $\begin{array}{r}17.3 \\
1.5\end{array}$ & $\begin{array}{r}33.6 \\
8.9\end{array}$ & $\begin{array}{r}51.2 \\
9.5\end{array}$ & $\begin{array}{r}85.3 \\
6.4\end{array}$ & $\begin{array}{l}98.7 \\
11\end{array}$ & $\begin{array}{r}75.6 \\
7.2\end{array}$ \\
\hline 100 & $\begin{array}{l}p_{3} \\
\mathrm{SE}\end{array}$ & $\begin{array}{r}38.0 \\
8.2\end{array}$ & $\begin{array}{r}59.1 \\
6.6\end{array}$ & $\begin{array}{r}60.5 \\
7.0\end{array}$ & $\begin{array}{r}86.2 \\
6.2\end{array}$ & $\begin{array}{r}36.9 \\
3.0\end{array}$ & $\begin{array}{l}44.4 \\
10\end{array}$ & $\begin{array}{r}48.0 \\
5.1\end{array}$ & $\begin{array}{r}97.6 \\
6.0\end{array}$ & $\begin{array}{r}107 \\
11\end{array}$ & $\begin{array}{r}90.5 \\
6.3\end{array}$ \\
\hline 60 & $\stackrel{p_{3}}{\mathrm{SE}}$ & $\begin{array}{r}91.9 \\
5.5\end{array}$ & $\begin{array}{r}120 \\
6.0\end{array}$ & $\begin{array}{c}101 \\
8.2\end{array}$ & $\begin{array}{r}123 \\
6.8\end{array}$ & $\begin{array}{r}102 \\
5.3\end{array}$ & $\begin{array}{c}145 \\
12\end{array}$ & $\begin{array}{r}95.3 \\
4.5\end{array}$ & $\begin{array}{r}144 \\
5.2\end{array}$ & $\begin{array}{r}137 \\
5.9\end{array}$ & $\begin{array}{c}148 \\
7.9\end{array}$ \\
\hline 40 & $\stackrel{p_{3}}{\mathrm{SE}}$ & $\begin{array}{r}121 \\
4.0\end{array}$ & $\begin{array}{r}151 \\
4.6\end{array}$ & $\begin{array}{c}120 \\
9.9\end{array}$ & $\begin{array}{r}153 \\
5.3\end{array}$ & $\begin{array}{c}133 \\
4.7\end{array}$ & $\begin{array}{r}166 \\
16\end{array}$ & $\begin{array}{r}135 \\
10\end{array}$ & $\begin{array}{r}181 \\
3.1\end{array}$ & $\begin{array}{r}177 \\
5.2\end{array}$ & $\begin{array}{r}184 \\
3.8\end{array}$ \\
\hline 30 & $\begin{array}{l}p_{3} \\
\mathrm{SE}\end{array}$ & $\begin{array}{r}129 \\
5.3\end{array}$ & $\begin{array}{l}146 \\
2.1\end{array}$ & $\begin{array}{r}121 \\
8.0\end{array}$ & $\begin{array}{l}149 \\
3.0\end{array}$ & $\begin{array}{r}138 \\
4.0\end{array}$ & $\begin{array}{r}149 \\
11\end{array}$ & $\begin{array}{c}132 \\
4.1\end{array}$ & $\begin{array}{r}158 \\
2.2\end{array}$ & $\begin{array}{c}158 \\
3.4\end{array}$ & $\begin{array}{c}159 \\
3.0\end{array}$ \\
\hline 20 & $\begin{array}{l}p_{3} \\
\mathrm{SE}\end{array}$ & $\begin{array}{r}121 \\
3.7\end{array}$ & $\begin{array}{r}118 \\
3.5\end{array}$ & $\begin{array}{r}114 \\
8.5\end{array}$ & $\begin{array}{c}120 \\
3.8\end{array}$ & $\begin{array}{r}122 \\
2.8\end{array}$ & $\begin{array}{r}120 \\
4.6\end{array}$ & $\begin{array}{c}120 \\
3.8\end{array}$ & $\begin{array}{r}122 \\
2.5\end{array}$ & $\begin{array}{r}123 \\
4.1\end{array}$ & $\begin{array}{r}121 \\
3.2\end{array}$ \\
\hline 15 & $\stackrel{p_{3}}{\mathrm{SE}}$ & $\begin{array}{r}107 \\
4.3\end{array}$ & $\begin{array}{r}91.6 \\
4.5\end{array}$ & 二 & $\begin{array}{r}94.4 \\
3.6\end{array}$ & $\begin{array}{l}103 \\
2.4\end{array}$ & $\begin{array}{r}91.7 \\
3.4\end{array}$ & $\begin{array}{r}101 \\
5.4\end{array}$ & $\begin{array}{r}96.4 \\
2.6\end{array}$ & $\begin{array}{r}101 \\
3.8\end{array}$ & $\begin{array}{r}93.3 \\
3.4\end{array}$ \\
\hline 10 & $\begin{array}{l}\bar{p}_{3} \\
\mathrm{SE}\end{array}$ & $\begin{array}{r}78.4 \\
7.1\end{array}$ & $\begin{array}{r}58.9 \\
6.8\end{array}$ & - & $\begin{array}{r}64.5 \\
3.8\end{array}$ & $\begin{array}{r}76.8 \\
2.8\end{array}$ & $\begin{array}{r}62.2 \\
3.8\end{array}$ & $\begin{array}{r}75.4 \\
4.3\end{array}$ & $\begin{array}{r}67.3 \\
2.1\end{array}$ & $\begin{array}{r}66.6 \\
4.3\end{array}$ & $\begin{array}{r}67.7 \\
2.2\end{array}$ \\
\hline & $N$ & 11 & 13 & 3 & 14 & 15 & 7 & 6 & 43 & 18 & 25 \\
\hline & $\bar{D}$ & 301 & 345 & 316 & 373 & 288 & 314 & 319 & 377 & 379 & 375 \\
\hline
\end{tabular}

cases, in each subdivision is indicated, as is the mean total ozone amount $\bar{D}(\mathrm{~m}$ atm-cm) for the subdivision, as determined by a Dobson spectrophotometer.

It is readily apparent, by application of the Student " $t$ " test using small-sample theory, that the differences of mean distributions of ozone as between synoptic classes, seasons, and stations are significant at better than the $1 \%$ level at a number of pressure levels. However, the last two columns also indicate possibly significant differences, in good agreement with those found by Dütsch (1966) for the seasonal means, between the same class and season in different years at Boulder. This suggests caution in interpreting the differences between the two stations as being interhemispheric rather than due to the difference in the years of observation.

The results indicate a great deal about the synoptic climatology of ozone, only some of which can be dis- cussed here. First it is clear within either "season," that the ozone distribution varies significantly with the position of the $300-\mathrm{mb}$ ridges and troughs, and with the middle latitude jet stream. Nevertheless, a large part of the total variance of the population is explicable only in terms of a seasonal variation not accounted for by the $300-\mathrm{mb}$ synoptic classification. This could perhaps be accounted for by variations in the intensity and depth of the systems, but seems more likely to be the result of a controlling seasonal influence in the middle stratosphere at or above the level at which the differences between classes disappear.

The differences between classes extend from tropospheric levels to about the 25-mb level, both at Aspendale and Boulder. The differences between seasons for the same classes, however, extend at least as high as the $10-\mathrm{mb}$ level. There is more ozone above $20 \mathrm{mb}$ in summer-autumn than in winter-spring, and less in the 

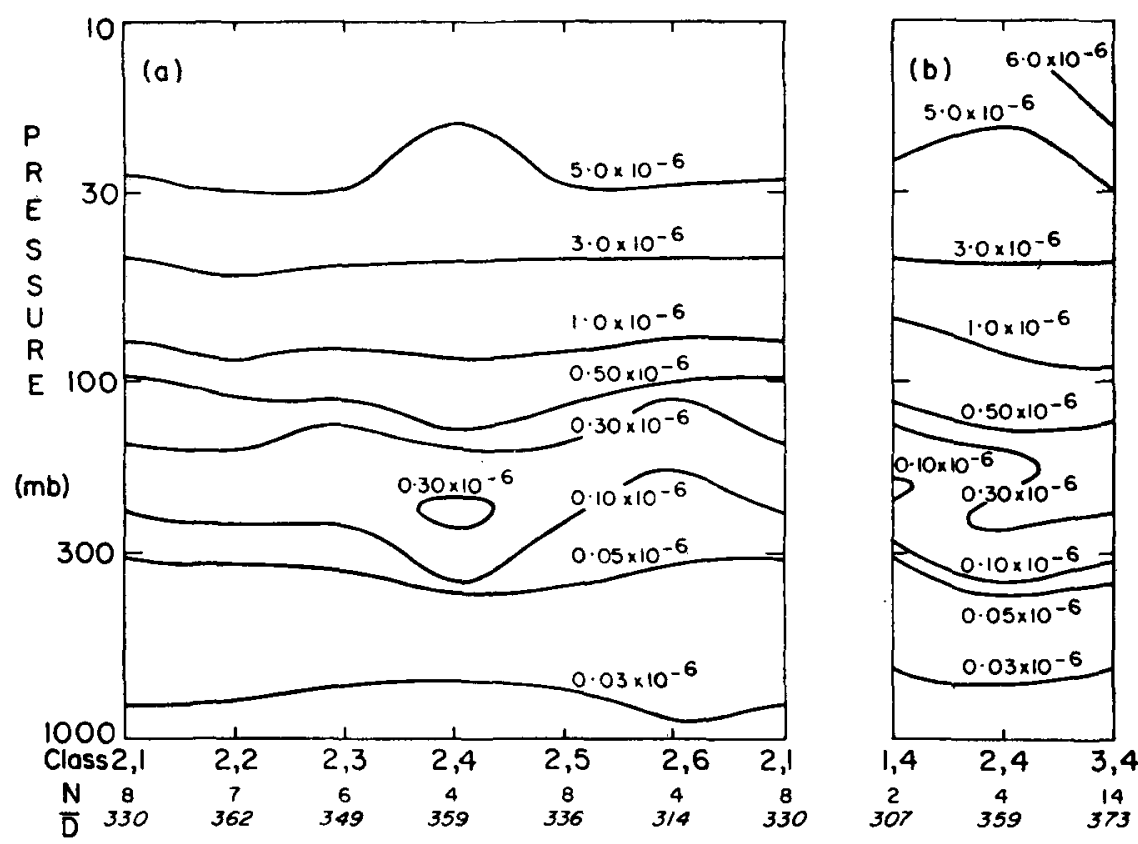

FIG. 1. Zonal, a., and meridional, b., cross sections of ozone number mixing ratio along row 2 and column 4 (trough), respectively, from soundings over Aspendale in the winter-spring season. Number of soundings $N$, and mean total ozone amount $D$ (m atm-cm) are indicated for each class designation $(i, j)$. See text for details.

lower stratosphere. This suggests less coupling between the lower stratospheric circulation and the stratosphere above $20 \mathrm{mb}$ in summer-autumn than in winterspring, with less exchange between them.

"Zonal" and "meridional" cross sections of ozone number mixing ratio for winter-spring at Aspendale (along row 2 and column 4, respectively) are shown in Fig. 1. These indicate the "folding-in" of stratospheric air into the troposphere, and vice-versa, in the vicinity of the middle-latitude jet stream along the $300-\mathrm{mb}$ trough. It is somewhat remarkable that the folding has occurred at so nearly the same levels in the several cases over Aspendale as to show up in the mean picture. The secondary maximum in ozone partial pressure is in fact significant at better than the $5 \%$ level in class $(2,4)$.

On the other hand, the mean cross sections for Boulder, not reproduced here, do not show this folding, although large secondary maxima are frequently observed at various levels in the individual soundings (Dütsch, 1966). This suggests greater variability in the height at which folding occurs over Boulder, perhaps due to the more perturbed circulation of the Northern Hemisphere, and in particular the effect of the Rocky Mountains.

Boulder has significantly more ozone than Aspendale, in class $(3,4)$ in winter-spring, both in the $30-60 \mathrm{mb}$ layer and in the 140-200 mb layer. Differences in these layers between Boulder and Aspendale are not significant in class $(1,2)$, nor in class $(3,4)$ in summer- autumn. Further, there is significantly more ozone in the $30-60 \mathrm{mb}$ layer in class $(3,4)$ over Boulder in winter-spring than in either classes $(1,4)$ or $(3,1)$, the difference being about $10-15 \%$. No such difference is apparent over Aspendale.

While the Aspendale means are not well determined in some classes due to insufficient soundings, these results strongly suggest that the ridge-trough-jet stream synoptic system is more effective in the transport of ozone in the middle stratosphere over Boulder in 196365 than over Aspendale in 1965-68. Study of concurrent sounding series will be necessary in order to decide whether this is an inter-hemispheric or longitudinal difference rather than a time variation (Pittock, 1968).

These preliminary results are in broad agreement with the literature on the variation of ozone content with synoptic weather patterns (Briggs and Roach, 1963; Craig, 1965; Danielsen, 1968). They indicate the great value of a more detailed analysis both of single-station and of network soundings. They also demonstrate that very large numbers of routine soundings are necessary for any rigorous statistical analysis to be possible.

Acknowledgments. Thanks are due to Dr. C. H. B. Priestley, Mr. W. C. Swinbank and other members of the Division, particularly Dr. R. N. Kulkarni and the ozone group, for their support and advice. 


\section{REFERENCES}

Briggs, J., and W. T. Roach, 1963: Aircraft observations near jet streams. Quart. J. Roy. Meteor. Soc., 89, 225-247.

Craig, R. A., 1965: The Upper Atmosphere: Meteorology and Physics. New York, Academic Press, 509 pp.

Danielsen, E. F., 1968: Stratospheric-tropospheric exchange based on radioactivity, ozone and potential vorticity. J. Atmos. Sci., 25, 502-518.
Dütsch, H. U., 1966: Two years of regular ozone soundings over Boulder, Colorado. NCAR, Boulder, Colo., Tech. note TN-10, 443 pp.

Freien Universität, 1963-65: Freien Universität Berlin. Meteor. Abhandl., 35, Nos. 8-12; 45, Nos. 1-12; 54 Nos. 1-7.

Pittock, A. B., 1968: Seasonal and year-to-year ozone variations from soundings over south-eastern Australia. Quart. J. Roy. Meleor. Soc., 94, 563-575.

\section{CORRIGENDUM}

The article entitled "Performance Characteristics of Various Artificial Ice Nuclei Sources" by Charles I. Davis and Roger L. Steele (J. Appl. Meteor., 7, 667-673) contains errata on Figs. 1 and 3 on pages 669 and 671, respectively. The effectiveness of the North American acetone generator at $-10 \mathrm{C}$ should read $1.7 \times 10^{13}$ instead of $1.7 \times 10^{12}$. Likewise, the effective nuclei $\min ^{-1}$ value for the above generator should read $1.7 \times 10^{12}$ instead of $1.7 \times 10^{11}$. 